DOI: 10.20472/IAC.2018.038.037

\author{
CATHERINA SCHENCK \\ University of the Western Cape, South Africa
}

PHILLIP BLAAUW

North West University, South Africa

JACOBA VILJOEN

University of Johannesburg, South Africa

ELIZABETH SWART

University of the Western Cape, South Africa

\title{
MANAGING LANDFILLS AND WASTE PICKERS ON THEM IN SOUTH AFRICA: TOWARD RECOGNITION, ACCESS AND DIGNITY
}

\begin{abstract}
:
Good waste management is necessary to build sustainable and liveable cities. Recycling activities contributes to create these sustainable and liveable cities.

A key but unrecognised element in promoting recycling is the efforts of waste pickers who make a living from recycling mainline recyclables. This article aims to describe the approaches used on ten landfills in South Africa to manage waste pickers' access and daily activities. A multiple case study design and cross case analysis were used in this study. The Sustainable Livelihoods Framework (SLF) was used to analyse and explain the data. The results showed that waste management policies and practices directly influence the waste pickers' access to recyclable waste and their livelihoods. Finally we highlight the inclusionary and exclusionary practices which may guide inclusive, participatory and co productive practices for waste pickers in South Africa.
\end{abstract}

\section{Keywords:}

Waste pickers, sustainable livelihoods, recyclable waste, landfills, management, sustainable development 